\title{
GEOLOGIC/GEOMORPHIC MAP OF THE GALINDO QUADRANGLE (V-40), VENUS
}

\author{
By Mary G. Chapman
}

\section{INTRODUCTION}

The Galindo quadrangle ( $\mathrm{V}-40$; centered at lat $12.5^{\circ} \mathrm{S}$., long $255^{\circ}$ ) was geologically mapped at $1: 5,000,000$ scale under the Venus Data Analysis and Venus Geologic Mapping Programs as part of a project focused on the study of venusian geologic terrains containing assemblages of coronae, arachnoids, and novae; these are enigmatic circular features perhaps related to hot-spot volcanism. Mapping of the quadrangle indicates most coronae are related to extension zones, and some aligned coronae and corona-like features show systematic variations in age.

Standard photogeologic techniques were used to map the geology on the synthetic aperture radar (SAR) backscatter mosaic of V-40, which was generated by the radarimage data base gathered by the Magellan spacecraft, launched May 4, 1989. Ninety percent of the coverage of the Galindo quadrangle consists of left-looking radar images generated during mission cycle 1 (cycle 2 images cover a narrow swath across the bottom of the quadrangle). The incidence angles of the cycle 1 data within the map area vary from 35.5 degrees (at lat $25^{\circ} \mathrm{S}$.) to 44.9 degrees (at lat $0^{\circ}$; Plaut, 1993). Geologic mapping of the quadrangle was assisted by the altimetry, root mean square (rms) slope, emissivity, and reflectivity datasets (fig. 1$)^{1}$. The topography of coronae and other features was determined by stereoscope examination of synthetic parallax stereo images (Batson and others, 1978). Understanding of the morphology and history of deformation was enhanced by examination of three-dimensional perspective views of geologically significant features (Soderblom and others, 1993; Chapman and others, 1994).

The three-dimensional perspective renderings were generated by enhancing the image base from the Galindo quadrangle with spatial filtration, contrast exaggeration, and the addition of relief shading, as described by Kirk and others (1992). Elevation data from the Magellan global altimetric dataset (global topography data record (GTDR); Pettengill and others, 1991) were merged with pre-Magellan data to fill gaps, reprojected to register to the image, and smoothed at the resolution of the altimeter.

\section{GEOGRAPHIC SETTING}

The Galindo quadrangle is named after impact crater Galindo at about lat $23^{\circ} \mathrm{S}$., long $259^{\circ}$ and shows a com-

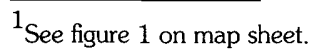

plex area containing a mixture of different types of volcanic constructs, fracture zones, and plains. The map area, west of Phoebe Regio, also contains a cluster of many symmetric, asymmetric, and multiple coronae, arachnoids, and novae that appear to be randomly distributed (Stofan and others, 1992). Trending northeast across the east half of the map area is a tessera high that is the terminal end of a western arm of Phoebe Regio. The map area contains one of the deepest sections of Parga Chasma, a fractured depression that trends northwest across the south half of the map area. Parga Chasma varies greatly in depth $(0$ to 3 $\mathrm{km})$ and is approximately $1,870 \mathrm{~km}$ long, roughly connecting Themis Regio (southeast of the map area at about lat $35^{\circ} \mathrm{S}$., long $285^{\circ}$ ) and Maat Mons (northwest of the map area at about lat $0^{\circ}$, long $195^{\circ}$ ).

\section{PREVIOUS WORK}

Venusian coronae in general are partly closed or closed, circular to irregular structures with maximum widths greater than $170 \mathrm{~km}$ (Pronin and Stofan, 1990). These features are defined by a dominantly concentric or circular structure consisting of an annulus of concentric ridges or fractures, an interior that is either topographically positive or negative, typically a peripheral moat or trough, and, commonly, numerous volcanic and tectonic landforms in the interior (Barsukov and others, 1986; Stofan and Head, 1990; Pronin and Stofan, 1990; Stofan and others, 1992; Squyres and others, 1992; Head and others, 1992a). Coronae are thought to represent the surface manifestation of mantle plumes, as the morphology of coronae and the proposed sequence of events in their evolution are consistent with corona formation by the ascent of a plume of hot mantle material to the base of the lithosphere (Schubert and others, 1989, 1990; Stofan and Head, 1990; Squyres and others, 1992; Stofan and others, 1992; Janes and others, 1992; Sandwell and Schubert, 1992). Coronae were first described by Barsukov and others $(1984,1986)$ using Venera 15 and 16 data; large circular structures of unknown origin had been identified in earlier radar images and topographic data of Venus (Schaber and Boyce, 1977; Campbell and Burns, 1980). Hansen and others (1992) document successive outward stepping of nested concentric fractures of coronae with time, continuing until the structure reaches an average diameter of about 600 to $800 \mathrm{~km}$, where the process appears to stop.

In contrast, arachnoids are corona-like features characterized by a concentric or circular pattern of fractures or ridges and radial fracture patterns or ridges extending out- 
ward for several radii (Head and others, 1992a). The areal distribution of arachnoids and coronae are very similar, as is their circular pattern. Arachnoids are more abundant at diameters less than $200 \mathrm{~km}$, and coronae predominate at diameters greater than $200 \mathrm{~km}$, suggesting that they may be related in origin and may be manifestations of similar processes at different scales (Head and others, 1992a). Extrusive volcanic features are not as common within arachnoids as they are within coronae, suggesting that magmatism associated with arachnoids is primarily intrusive (Head and others, 1992a).

Novae are defined as corona-like features that have prominent radial fracture patterns forming a star-burst or stellate pattern typically centered on a broad domical topographic high; they range in size from 50 to $300 \mathrm{~km}$, with the majority between 150 and $200 \mathrm{~km}$ (Head and others, 1992a). Novae commonly occur in association with arachnoids and coronae and show both apparent superposition and embayment relations with coronae. Therefore, novae may represent an intermediate stage in coronae formation or may represent coronae whose development has been arrested (Head and others, 1992a).

\section{STRATIGRAPHY}

Relative ages for most units were established by stratigraphic relations; however, some deposits without decipherable stratigraphy could only be mapped as undivided material units. Contacts are queried on some material units having questionable terminations or emission sources. The nature of side-looking geometry of the radar images makes terrain sloping toward the imaging sensors appear brighter and spatially compressed compared to terrain that slopes away from the sensors (Ford and Plaut, 1993). This peculiar topographic effect interacting with changing trends of morphologies created difficulties in geologic mapping. Surface roughness of units result in variation in brightness (Ford and Plaut, 1993) and, therefore, units with nearly identical surfaces are difficult to discriminate. Because of these unique characteristics of the Magellan images, many stratigraphic relations are based on very limited observable contacts, many contacts are dashed, and some tectonic features could only be mapped as lineaments.

The cumulative densities of craters are too low on Venus for determining ages at 1:5,000,000 scale. However, studies of impact craters on the entire planet of Venus from the Magellan images have led workers to hypothesize that some pervasive, near-global resurfacing event occurred a few hundred million years ago (Parmentier and Hess, 1992; Phillips and others, 1992; Schaber and others, 1992; Turcotte, 1993; Herrick, 1994). Additionally, Strom and others (1992) noted that a global resurfacing event yields thermal evolution results consistent with numerical calculations of mantle convection in Venus (Arkani-Hamed and Taksöz, 1984). Therefore, the present surface, which still could be active, and the age of coronae, arachnoids, and novae are no older than that resurfacing. However, due to the lack of crater counts, the age of a venusian geologic unit can only be determined from superposition relations of its distal materials, although these deposits may not be representa- tive of the entire age span of the unit. Therefore, materials can be older or younger than the stratigraphic age indicated on the unit correlation chart and placements on the chart should be considered data points without error bars.

The oldest unit in the map area consists of tessera material of Phoebe Regio (unit tpr). Tessera or complex ridge terrain (CRT; Bindschadler and Head, 1991) was defined as a terrain type characterized by a complexly deformed surface of ridges and troughs, intersecting at various angles, typically lying at higher elevations than surrounding materials, and likely resulting from extensive horizontal deformation (Basilevsky and others, 1986; Bindschadler and Head, 1989, 1991). The tessera material comprises the highland terrain of Chimon-mana Tessera (the western arm of Phoebe Regio) and some isolated hills. The tessera outcrops are locally mantled by small areas of tessera-embaying plains material (unit pt). These plains and tessera materials are in turn embayed by younger plains, coronae, and mons materials. Unit pt is not deformed by tessera ridges but is typically more radar bright than surrounding plains, probably because of denser fracturing or perhaps just a rougher surface. Some overlying contacts of flow fronts from younger plains units can be observed locally. Patera unit 1 (unit $\mathrm{cp}_{1}$; at about lat $6^{\circ} \mathrm{S}$., long $256^{\circ}$ ) is overlain by the same younger plains as the tessera-embaying plains material. The pateras in the map area are simple circular depressions associated with volcanic flows and are interpreted as likely calderas.

Two corona units mapped at approximately lat $9^{\circ} \mathrm{S}$., long $259^{\circ}$ are partly buried by younger plains. These corona units $\mathbf{a}$ and $\mathbf{b}$ (units $\mathrm{CO}_{\mathbf{a}}$ ? and $\mathrm{CO}_{\mathbf{b}}$ ) consist of partially buried annular ridges of single-ring coronae or possibly arachnoid features. Corona unit a is queried because of the limited area of the outcrop. The older age of the unit is also queried because the age interpretation is based on more advanced burial of the outcrops by younger plains and on its association with a deeper depression. Development of a topographic depression is the hypothetical end member of coronal evolutionary growth and may result from viscous relaxation of crust after a magma source is depleted and cooled (Stofan and others, 1992). Corona materials as mapped comprise corona and corona-like features (arachnoids and novae).

The tessera material of Phoebe Regio, tessera-embaying plains material, the two oldest corona units, and unit 1 of the patera material are overlain by radar-dark plains material (unit pd). Tessera and tessera-embaying plains materials are superposed east of Chimon-mana Tessera by unit 1 of the flow materials (unit $\mathrm{f}_{1}$ ). The delineation of radar-dark plains and flow unit 1 is somewhat subjective; however, the units differ in that the flow unit contains numerous small scattered tholi or volcanic cones, has a higher reflectivity, has slightly lower emissivity, and lies at higher elevations (fig. 1).

Radar-dark plains material (unit pd), patera unit 1 (unit $\mathrm{cp}_{1}$ ), and a mound mapped as mons unit a (unit $\mathrm{m}_{\mathrm{a}}$ ) are locally superposed by unit 2 of the flow materials (unit $f_{2}$ ). Mons units are digitate flows associated with large $(>75 \mathrm{~km}$ diameter) cone- or dome-shaped mountains that have been interpreted to be flank and radial lava of shield or exog- 
Table 1. Quantitative Magellan surface properties of all flow and plains materials on geologic map of Galindo quadrangle from chosen sample boxes. ${ }^{1}$

$\left[N\right.$ : number of pixels used in backscatter calculation; $\sigma_{\mathrm{o}}$ : backscatter cross section; $\varepsilon_{\mathrm{s}}, \varepsilon_{\mathrm{r}}$ : calculated dielectric constants for smooth and rough surface cases. For backscatter cross section, values in parentheses represent $\sigma_{\mathrm{O}}$ value (in $\mathrm{dB}$ ) at plus and minus one standard deviation. For all other data, values in parentheses represent minimum and maximum values of each parameter with the chosen sample box. Correlation chart shown on figure 9]

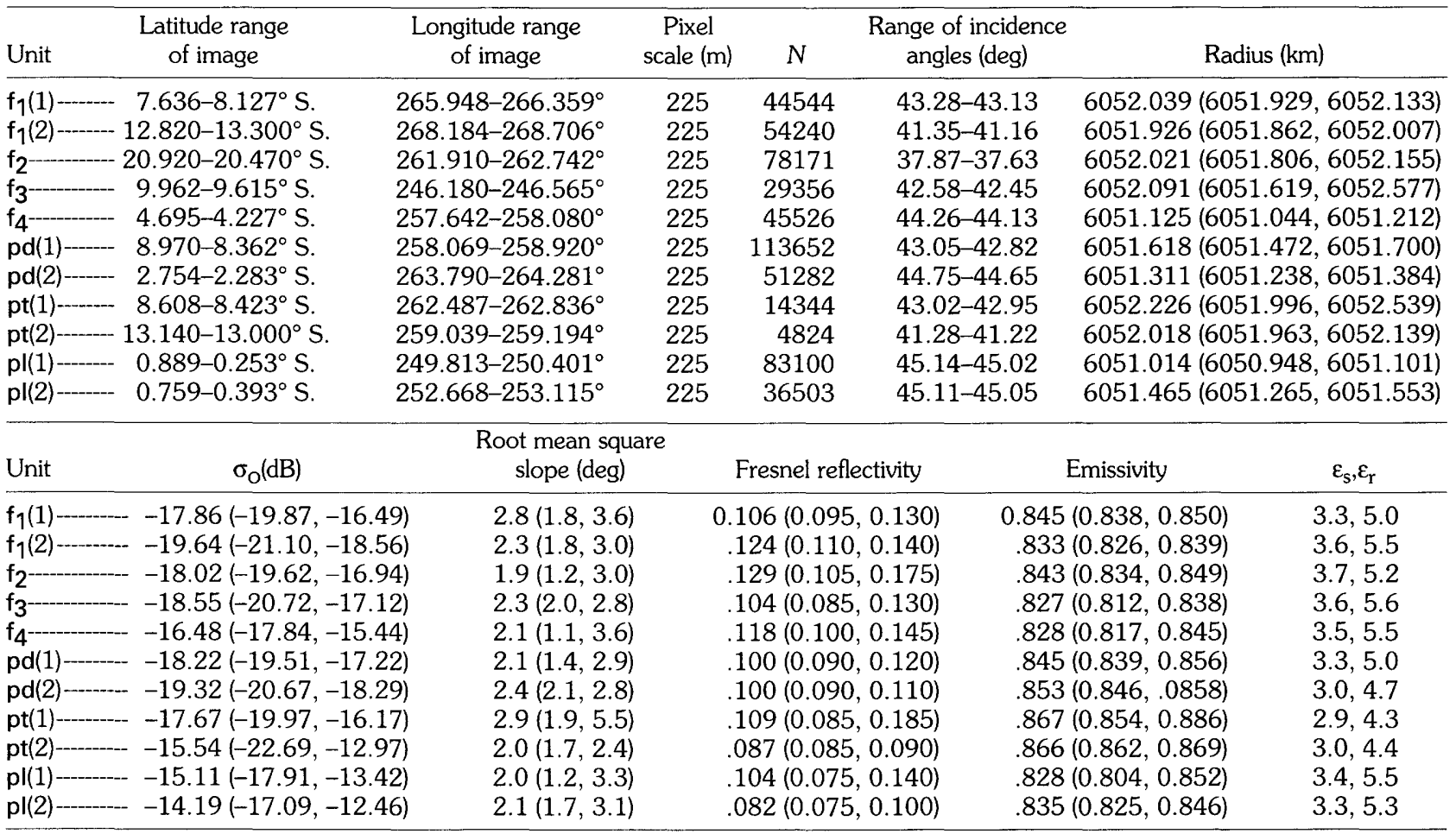

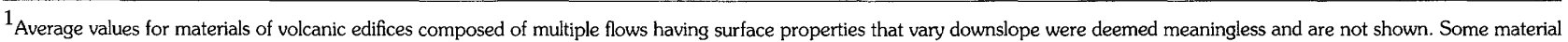
units are represented by two sample boxes; box sizes were chosen to avoid pervasive, post-depositional fractures.

enous dome-type volcanoes. At lat $20.5^{\circ} \mathrm{S}$., long $264.5^{\circ}$, flow unit 1 also appears to be embayed by unit 2 of the flow materials. On the north edge of the map area, flow unit 2 is overlain by radar-light plains material (unit pl). Radar-light plains material differs from other plains material in being slightly more fractured and in its relative radar reflectance (having a slightly higher backscatter coefficient) and emissivity (a lower value than many units; fig. $1 D, E$; table 1 ). Younger mons unit a flow material (unit $\mathrm{m}_{\mathrm{af}}$ ) can be traced to the much older unit $\mathrm{m}_{\mathrm{a}}$ volcanic edifice at lat $23.5^{\circ} \mathrm{S}$., long $262.5^{\circ}$ and also overlies flow unit 2 . The upper age limit of the $m_{\text {af }}$ flows are unrestricted, therefore the unit is queried. In the north-central part of the map area, unit 2 of the flow material is also overlain by patera material unit 2 (unit $\mathrm{cp}_{2}$ ) and coronae unit $\mathrm{c}$ (unit $\mathrm{co}_{\mathrm{C}}$ ). An arachnoid formally named Krumine Corona at lat $4^{\circ} \mathrm{S}$., long $261.5^{\circ}$ that overlies corona unit $\mathrm{c}$ has been mapped as material of corona unit $\mathrm{d}$.

Also in the north-central part of the map area, flows from two calderas (Viardot Patera and an unnamed patera) mapped as patera material unit 3 (unit $\mathrm{cp}_{3}$ ) overlie patera unit 2. One outcrop of patera unit 3 and an outcrop of mons unit $b$ (unit $\mathrm{m}_{\mathrm{b}}$ ) are embayed by flow of corona material unit e (unit $\mathrm{co}_{\mathrm{e}}$ ) that can be traced to a $525-\mathrm{km}$-wide, asymmetric corona in the central part of the map area.
Superposed on the asymmetric corona are cones and flows of younger mons materials. Some flows from the central asymmetric corona have been deformed by and therefore appear to predate Parga Chasma. For example, south of the corona the chasma is 2.5 to $3 \mathrm{~km}$ deep, and the earlier flows from the corona extend to the opposite side of the chasma. Other parts of the corona appear to be coeval with the chasma as the southeast section of the corona's moat or trough is a part of the chasma. Judging the age features such as coronae and Parga Chasma based on deformation patterns alone is suspect because of the phenomenon of rejuvenated sympathetic structural trends; however, it is a valid method in the data-limited field of planetary geology and one that has been previously used to relate coronae and extensional belts elsewhere on Venus (Baer and others, 1994).

At lat $9^{\circ} \mathrm{S}$., long $248.5^{\circ}$ flows of corona unit e from the central asymmetric corona are overlain by flows from Javine Corona at lat $5^{\circ} \mathrm{S}$., long $251^{\circ}$ mapped as corona unit $\mathrm{f}$ (unit $\mathrm{co}_{\mathrm{f}}$ ). Structures of the only two novae that occur in the map area are superposed on Javine Corona (fig. 2); however, their materials cannot be differentiated from those of Javine. Any materials of the novae are obscured by the numerous grabens that cut into the novae and the underlying corona (fig. 2). 


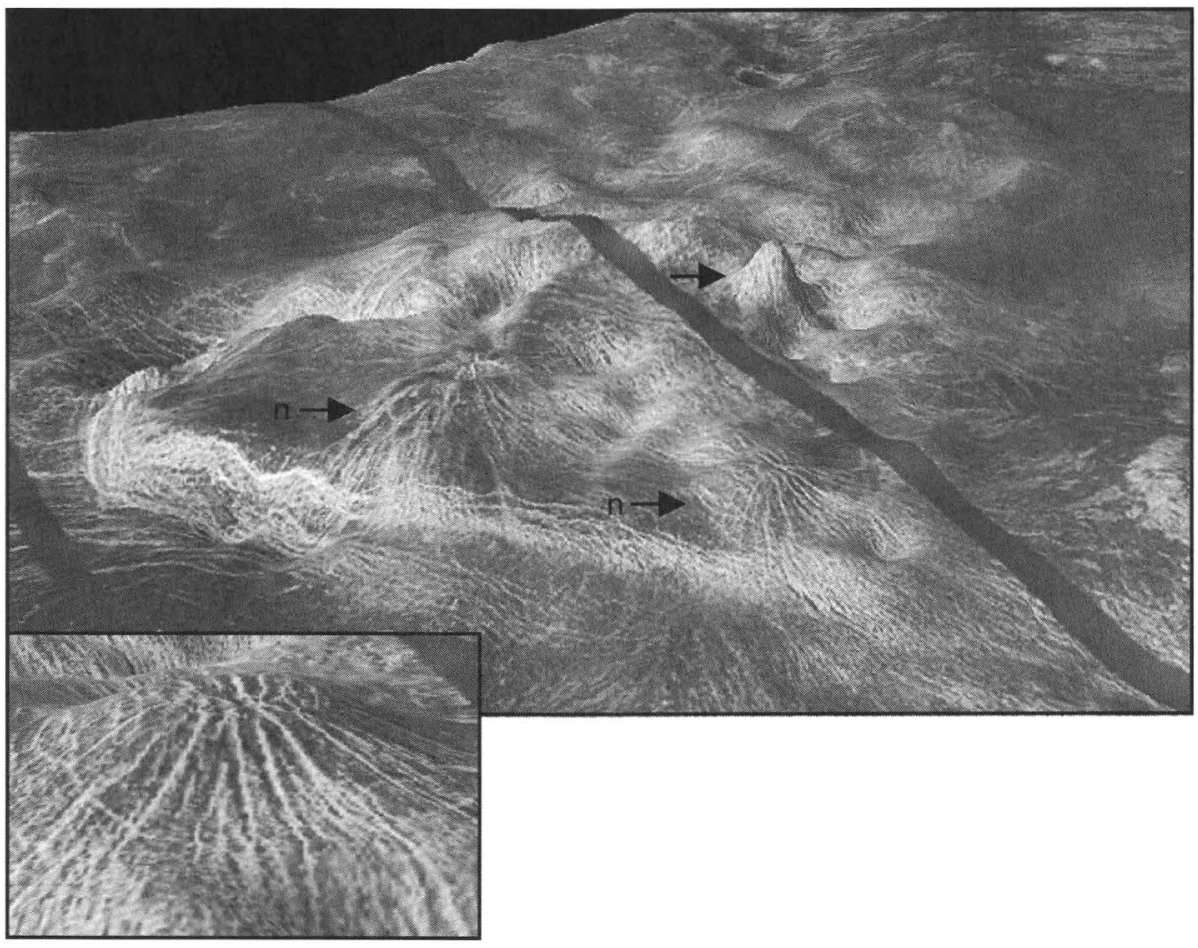

Figure 2. Three-dimensional perspective view (composed of left-looking synthetic aperature radar images; vertical exaggeration 10x; Kirk and others, 1992) of 500-kmlong Javine Corona looking northeast; corona centered at lat $5^{\circ} \mathrm{S}$., long $251^{\circ}$. Javine is an asymmetric corona overlapped by two novae (arrows marked " $n$ "). The prominent high (background arrow) on the corona is about the width of a single altimetry footprint and most likely represents a reading error. Box (left foreground) is an enlargement of southern nova and shows nova graben; view toward north.

Eastern flows of Javine Corona are overlain by flows and cut by trench fractures of corona unit $\mathrm{g}$ (unit $\mathrm{co}_{\mathrm{g}}$ ) at lat $3^{\circ} \mathrm{S}$., long $254.5^{\circ}$. Flows of patera unit 4 (unit $\mathrm{cp}_{4}$ ) that were emitted from a caldera at lat $3^{\circ} \mathrm{S}$., long $257^{\circ}$ are interbedded between the concentric corona's flows (unit $\mathrm{co}_{\mathrm{g}}$ ) and those of an arachnoid to the north mapped as corona material unit $\mathrm{h}$ (unit $\mathrm{co}_{\mathrm{h}}$; fig. 3). This relation is repeated to the east, where the caldera's flows are interbedded between another two arachnoids. The eastern arachnoids have been mapped as corona units $\mathrm{i}$ and $\mathrm{j}$ (units $\mathrm{Co}_{\mathrm{i}}$ and $\left(\mathrm{o}_{\mathrm{j}}\right.$ ) and, based on identical relations, could be the same ages as units $\mathrm{g}$ and $\mathrm{h}$, respectively. However, the older, eastern unit i arachnoid could be as old as material of corona unit $\mathrm{f}$, but the lower age limit of unit $\mathrm{i}$ can only be placed with respect to materials of corona unit $d$.

Southwest of Javine Corona, its flows are locally superposed by deposits of unit 3 of the flow materials (unit $f_{3}$ ). Outcrops of flow unit $\mathbf{3}$ are the youngest flows and they occur in various locations in the map area. Most of the material appears to have been emitted from small tholi (such as Sumerla Tholi) that form on material as old as corona unit $\mathbf{e}$ and as young as corona unit $\mathrm{I}$.

Deposits of flow unit 3 are overlain to the south by flows of corona unit $\mathrm{k}$ (unit $\mathrm{co}_{\mathrm{k}}$ ) that were emitted from asymmetric Atete Corona (lat $16^{\circ} \mathrm{S}$., long $244^{\circ}$ ), whose north boundary forms a mostly 1-km-high cliff above Parga
Chasma (fig. 4). This portion of Parga is an arcuate segment that curves sharply to define the corona's boundary (Schubert and others, 1994). A volcanic center within the corona erupted lava that was truncated and uplifted with the north end of the corona during the formation of Parga Chasma, giving the appearance that the lava flowed upslope (fig. 5). Because the moat or trough of Atete contains a section of Parga Chasma, the growth of Atete had to be coeval with development of Parga Chasma. Flows of Atete are interbedded with and, therefore, likely the same age as flows from Dhorani Corona to the north at lat $8^{\circ} \mathrm{S}$., long $243^{\circ}$. At about lat $9^{\circ} \mathrm{S}$., long $246^{\circ}$, a 1.5 -km-high cone mapped as mons unit $\mathrm{c}$ (unit $\mathrm{m}_{\mathrm{c}}$ ) erupted two flows (units $\mathrm{m}_{\mathrm{cf} 1}$ and $\mathrm{m}_{\mathrm{cf} 2}$ ) that overlie corona unit $\mathrm{k}$ material. Flow unit one could be impact melt from a possible transverse impact crater (Storni crater; dark area central to the flow). However, as the voluminous unit one flow can be traced up the slope of the unit $\mathrm{c}$ mons and the dark area known as Storni lacks a rim, the former interpretation is preferred.

Flows of corona material unit I (unit $\mathrm{co}_{\mid}$) from Dilga Corona superpose corona unit $\mathrm{k}$ at lat $20^{\circ} \mathrm{S}$., long $248.5^{\circ}$. Some grabens and fractures that emerge from Parga Chasma extend south away from the Parga depression to Dilga Corona, where the structures form part of the corona's annulus. Therefore, emplacement of corona unit I likely was coeval with the development of Parga Chasma. Flows 


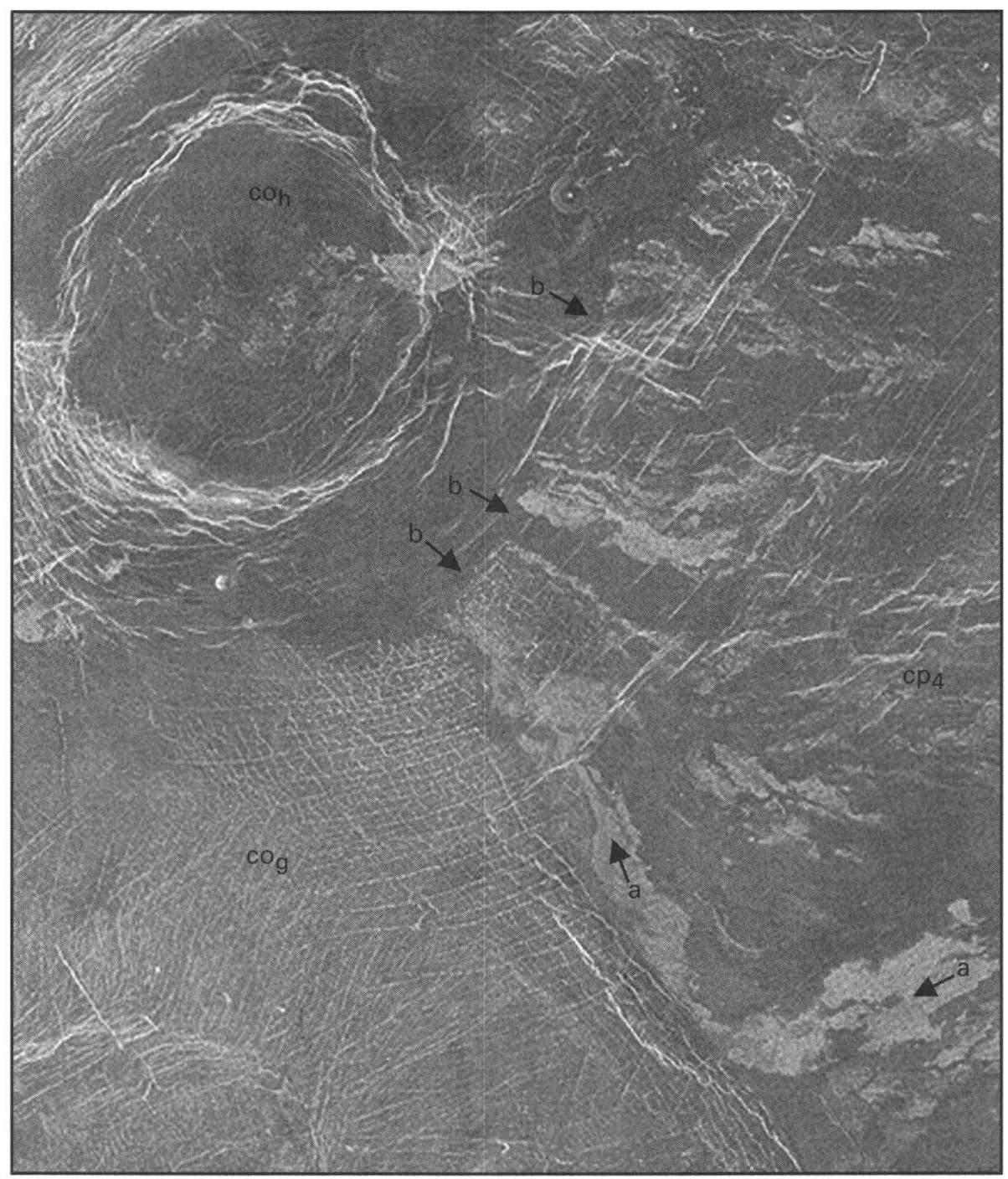

Figure 3. Left-looking, synthetic aperture radar image centered at lat $2^{\circ} \mathrm{S}$., long $255^{\circ}$ showing stratigraphic relations of units; annulus ring of arachnoid (mapped as corona unit $\mathrm{h}, \mathrm{co}_{\mathrm{h}}$ ) in upper left corner is about $70 \mathrm{~km}$ wide; north toward top. Volcanic flows (marked "a") of patera unit $4\left(\mathrm{cp}_{4}\right)$ flowed toward and changed direction after they encountered preexisting topography of older material of corona unit $\mathrm{g}\left(\mathrm{co}_{\mathrm{g}}\right)$. These flows are in turn overlain by material (marked "b") from corona unit $\mathrm{h}$.

of Dilga Corona are overlain by outcrops of corona units $\mathrm{m}$ and $\mathrm{n}$ (units $\mathrm{Co}_{\mathrm{m}}$ and $\mathrm{Co}_{\mathrm{n}}$ ). Both outcrops of corona units $\mathrm{m}$ (from Lalohonua Corona) and $\mathrm{n}$ have associated annulus rings deflected and deformed to be symmetrical with structures of Parga Chasma, indicating the corona units $\mathrm{m}$ and $\mathrm{n}$ also were coeval with the formation of Parga. Materials of corona unit $\mathrm{n}$ overlie those of mons unit $\mathrm{d}$ (unit $\mathrm{m}_{\mathrm{d}}$ ) and are in turn superposed by outcrops of mons units $\mathbf{e}$ and ef (units $\mathrm{m}_{\mathrm{e}}$ and $\mathrm{m}_{\mathrm{ef}}$ ) and corona unit o (unit $\mathrm{co}_{\mathrm{o}}$ ). The material of corona unit o was emitted from Nagavonyi Corona, a multiple corona at lat $18.5^{\circ} \mathrm{S}$., long $259.5^{\circ}$. The east sections of Nagavonyi's annular rings are deflected from their circular paths to form straighter trends that match the trends of grabens extending out of Parga Chasma. Where these Parga Chasma graben cut the flank of Nagavonyi, they emit flows mapped as queried corona unit o material. The unit designation of the flows is based on the interpretation that the deposits are flank fissure flows from Nagavonyi. The distortion of Nagavonyi's rings and the possible flank flows suggest that unit o also was deposited in conjunction with the development of Parga Chasma.

The apparent interrelation of Parga chasma and coronae growth is repeated in the southeast corner of the map area. Mostly south of the map area, at about lat $26^{\circ} \mathrm{S}$., long $269^{\circ}$, is Hervor Corona, whose flows comprise the stratigraphically lowest material of three coronae in the southeast corner of the map area. (The other two coronae, Chuku Corona and an unnamed corona, are younger than Hervor and are within the map area). Hervor's annulus rings and flows are deformed by Parga, as are the annulus 


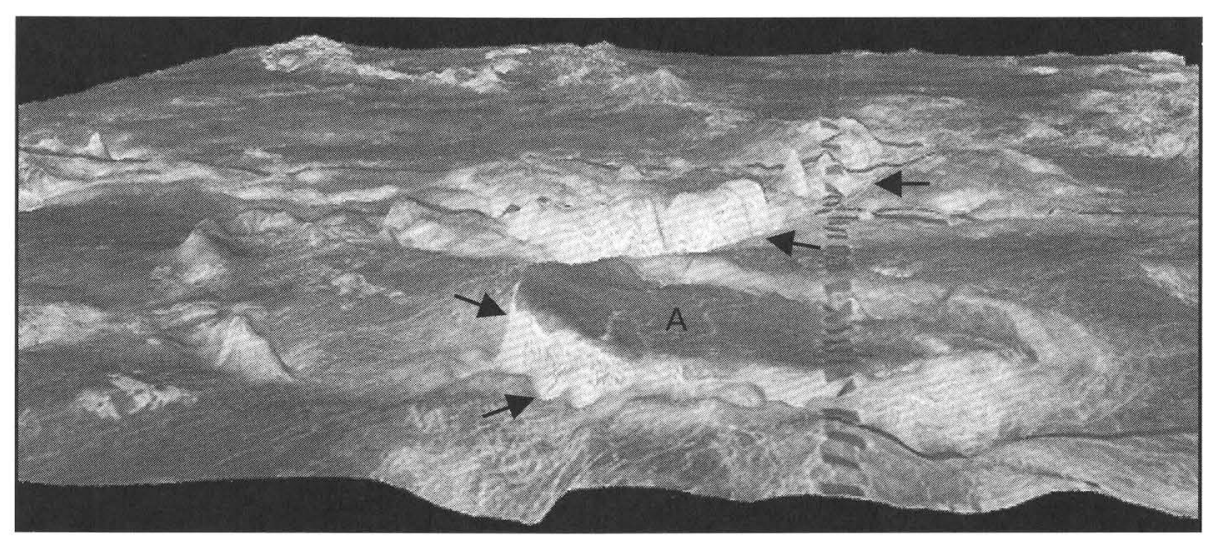

Figure 4. Three-dimensional perspective view (Kirk and others, 1992) of most of Galindo quadrangle (composed of left-looking synthetic aperature radar images; vertical exaggeration $10 \times$ ), looking east, shows topographic variation within the quadrangle. Atete Corona $\left(600 \mathrm{~km}\right.$ long, lat $16^{\circ} \mathrm{S}$., long $\left.244^{\circ}\right)$ marked by "A." Arrows point to deepest section of Parga Chasma.

rings of the other two southeast coronae and, therefore, all three likely grew in conjunction with Parga Chasma. However, the coronae's materials are too far from other corona materials to establish stratigraphic ages, so they have been mapped as undivided coronae material (unit co). Material from a fourth corona off the map area to the southeast underlies Hervor but is not close enough to Parga to show any relations to the chasma. This deposit is also mapped as undivided corona material (unit co?) as are a few outcrops of corona material on the north edge of the map area that have indiscernible stratigraphic histories. The outcrops are queried because their terminations are difficult to observe.

The flows and the source caldera, Wilde Patera, of undivided patera material (unit $\mathrm{cp}$ ) in the southeast corner of the map area are so mapped because of the questionable age of the overlying corona materials. Another small outcrop of undivided patera material occurs superposed on northeastern Javine Corona.

The mons unit $\mathrm{m}_{\mathrm{f}}$ comprises the large 2-km-high Uretsete Mons cone and associated radial flows that embay and bury part of the tessera material exposed in the arm of Phoebe Regio and overlie corona unit o. Some of this lava flowed northwest to come to rest in a depression associated with corona unit a. The eastern part of Uretsete Mons is cut by grabens from an east-west-trending extension zone (Rabie Chasma) that ends abruptly at the top of the volcano.

Some minor aeolian materials are evident in the quadrangle, but these have not been mapped due to the limited nature of the outcrops. A 30-km-long wind streak trending northeast from a tholus lies at about lat $9.4^{\circ} \mathrm{S}$., long $247.7^{\circ}$ and apparent aeolian reworking of a small tholi field occurs at lat $1^{\circ} \mathrm{S}$., long $263.5^{\circ}$. Some minor impact crater materials (units $\mathrm{c}$ and $\mathrm{cf}$ ) occur superposed on older materials within the map area; some craters are cut by Parga Chasma fractures.

\section{STRUCTURE}

Numerous fractures crosscut the map area; the majority have been mapped as grabens, indicating a mostly tensional stress field acting across the map area. Grabens and fractures line the sides of Parga Chasma, a depression that varies in depth from 0 to $3 \mathrm{~km}$ within the map area. Northwest-trending grabens of Parga extend hundreds of kilometers, cutting into the tops of nearby coronae and forming sections of coronae troughs. A secondary, perpendicular graben set also occurs within the chasma, but these grabens are not as extensive.

Parga intersects the trend of the tessera high that is the terminal end of a northeast-trending, western arm of Phoebe Regio. Southwest of that intersection, tessera occurs as several isolated hills following the same northeast trend as the Phoebe Regio arm. After its intersection with the tessera high, the chasma is offset $200 \mathrm{~km}$ to the south. The rift along the southeast branch of Parga is offset to the south probably because this is where the chasma encountered texturally and possibly dimensionally different material of the Phoebe Regio tessera trend and the elevated terrain southwest of it (figs. $1 B, 5$ ). Radar-dark plains are elevated $500 \mathrm{~m}$ within an average $50 \mathrm{~km}$ of their contact with the west side of Phoebe Regio tessera (fig. 1B). The elevation change could be due to continued uplift of the tessera or subsidence within the plains.

One of the deepest sections of the northwest-trending depression of Parga Chasma lies within the map area (fig. 1B). Part of the deep section follows an arcuate path about the north end of Atete Corona, forming part of the corona's moat or outer trench. Another less dominant fracture zone with associated coronae extends from the convex edge of this path to the northeast, forming a triple junction with Parga (fig. 6). This northeast triple junction forms a 2-km-deep depression and part of the west moat of 


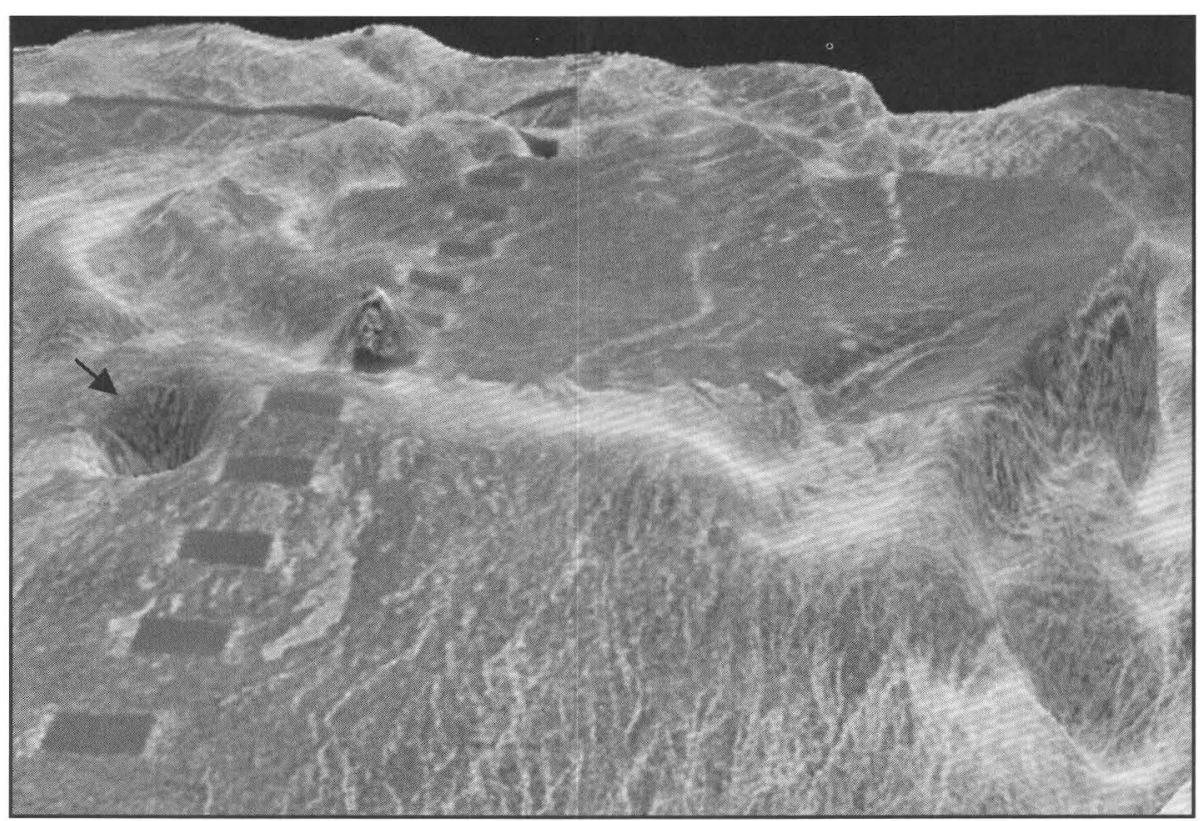

A

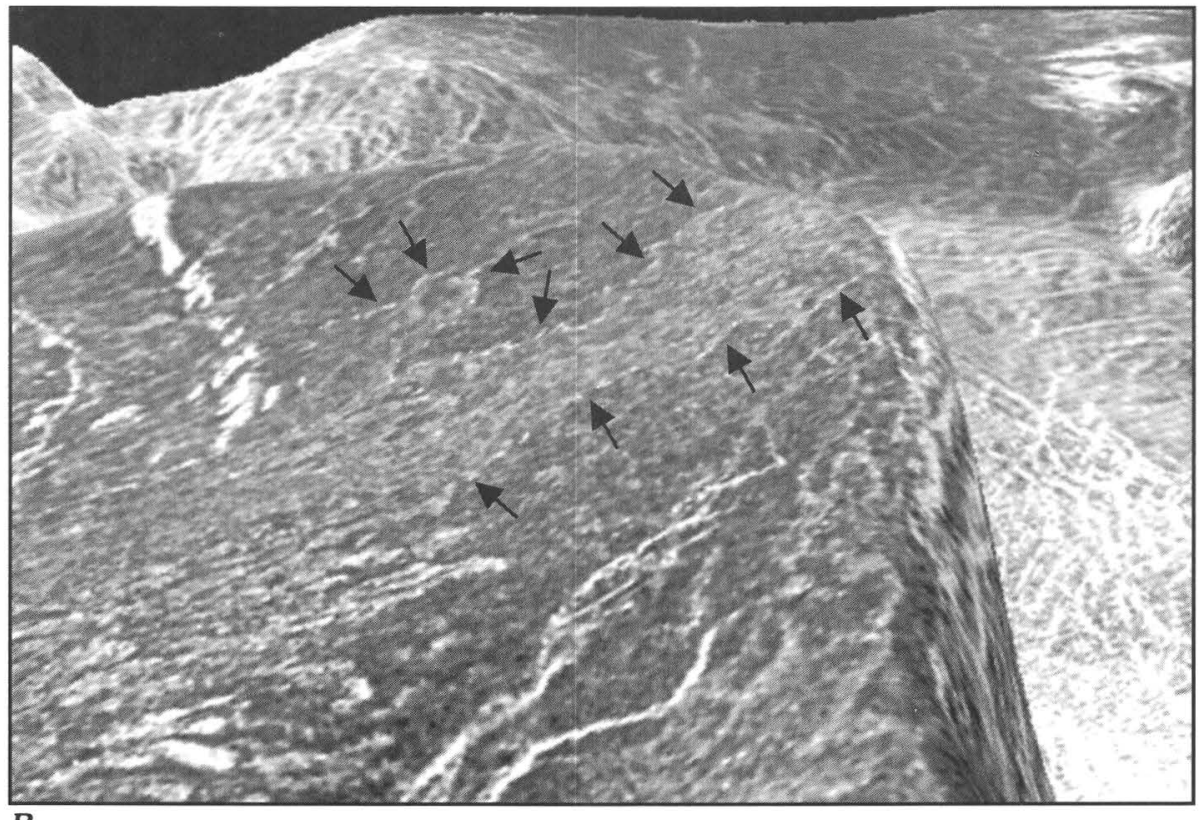

B

Figure 5. Three-dimensional perspective view (composed of left-looking synthetic aperature radar images; vertical exaggeration 10x; Kirk and others, 1992) of 600-kmlong Atete Corona (shown in fig. 4) looking west; corona centered at lat $16^{\circ} \mathrm{S}$., long $244^{\circ}$. A, Full view showing corona mesa and north-facing cliff that is part of Parga Chasma and part of corona trench; prominent low (arrow) is about the width of a single altimetry footprint and likely represents a reading error. $B$, Close-up view of north part of corona; arrows mark edges of lava flow truncated by faulted uplift of north end of corona.

another unnamed asymmetric corona (at about lat $12.5^{\circ}$ S., long $250^{\circ}$ ); Parga also forms this unnamed corona's south moat.

A 38-mgal positive gravity anomaly and a small positive geoid height are associated with Atete Corona, and these data have led Schubert and others (1994) to postulate formation by either thermally induced thickness variations in a moderately thick (about $100 \mathrm{~km}$ ) lithosphere or a deep positive mass anomaly due to subduction or underthrusting. These authors prefer the interpretation that the gravity anomaly is due to a buried mass anomaly resulting from subduction, because the anomaly is associated with the 


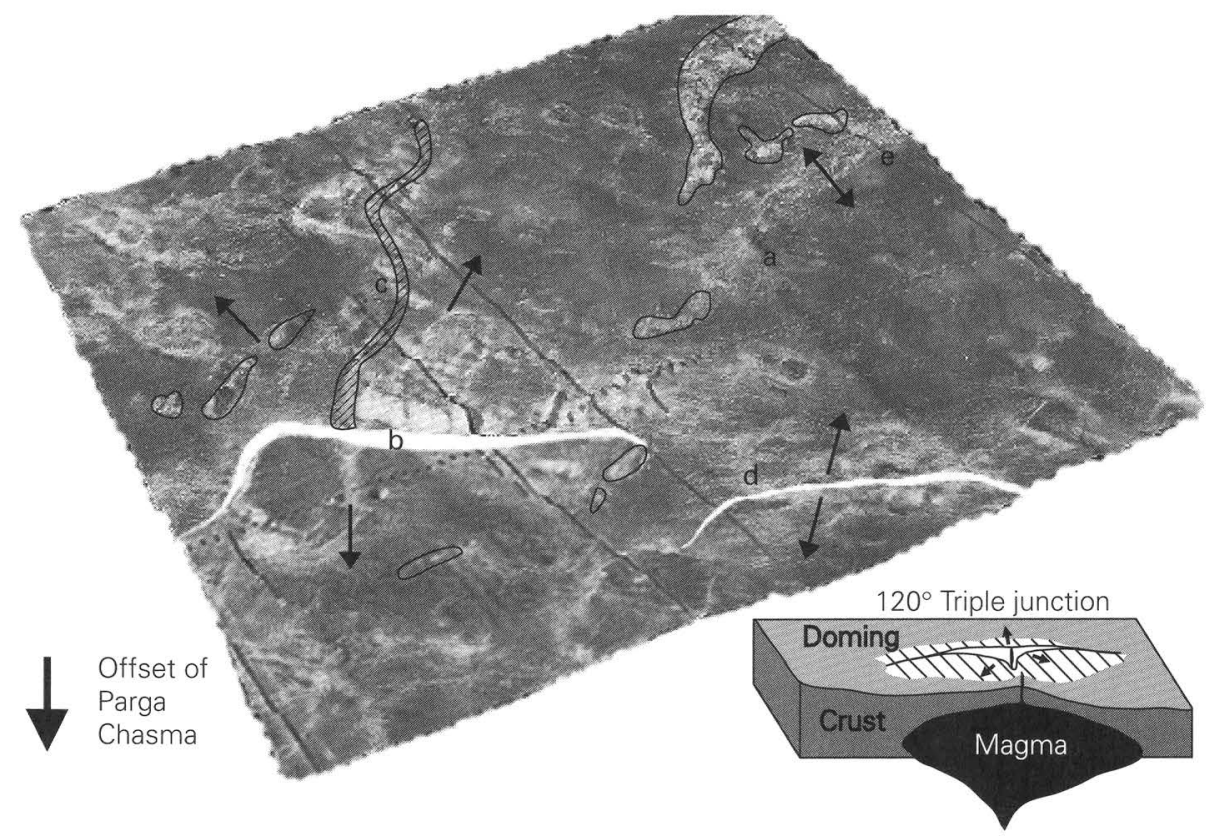

Figure 6. Three-dimensional perspective view of Galindo quadrangle (composed of leftlooking synthetic aperature radar images; vertical exaggeration 10x; Kirk and others, 1992) with illustrations; north is toward top; tessera outlined in black; arrows indicate inferred direction of surface movement; quadrangle is approximately $3,300 \mathrm{~km}$ wide. Flows from 2-km-high Uretsete Mons (marked "a") embay arm of Phoebe Regio, named Chimon-mana Tessera. Deepest section of Parga Chasma indicated by white zone marked "b." Cross-hatched zone marked "c" is less deformed fracture zone trending northeast away from Parga. White zone marked "d" is an extension of Parga Chasma offset to south after encountering trend of tessera high. Relatively young extension zone of Rabie Chasma marked "e" intersects volcano. Diagram in corner shows surface movement away from triple junction fracture zone possibly similar to that formed by zones marked "b" and "c" on quadrangle.

concave side of the arcuate segment of Parga together with the absence of similar high gravity anomalies over other portions of the same chasma.

However, map relations of the V-40 quadrangle do not appear to support subduction at Parga. The prolific number of grabens in the map area and possibly the broken, extended nature of the Phoebe Regio belt argue for extension. In addition, no evidence exists of a compressed highland or arc along and coeval with Parga Chasma. Furthermore, the arcuate bend of Parga seems to form part of a triple junction rift zone (fig. 6). Coronae, along both Parga and the less dominant northeast fracture zone, may represent rift-type clusters of aligned eruptive vents. In terrestrial rift zones, most of the basaltic section is likely to be erupted from an elevated region above a rift and flow laterally away from the rift onto an adjacent continent (White and others, 1989). The placement of coronae on mostly opposite sides of Parga Chasma and their extensive flows away from the chasma are in agreement with this terrestrial eruption mode.

The three branches of the Parga triple junction suggest a "least effort" fracture as a result of magma-induced vertical upward loading (Luongo and others, 1991), possibly related to local mantle upwelling of a quasi-stationary hot-spot plume that could result in thermally induced crustal thickening. Movement of the surface above the plume would tend to be uplift above and extension away from the triple junction (fig. 6).

One of the last structural events in the map area was the formation of a zone of east-west-trending grabens (Rabie Chasma) that cut the top of very young Uretsete Mons at lat $13^{\circ} \mathrm{S}$., long $262^{\circ}$. This extension zone does not occur west of Uretsete volcano, although it may have been buried there by late-stage eruptions from Uretsete.

\section{CORONAE GROWTH}

Most of the coronae in the map area have served as the source of numerous digitate volcanic flows. The mapping of these flows has served as the primary basis for determining the stratigraphic placement of each corona. Individual corona units, however, contain materials of differing ages, which were not split out because the map emphasis is on the relation between coronae and not on the details of individual corona. Some coronae lack discernible flows and are only represented by an increased density of mapped structures and the presence of structures peculiar to coronae. Three corona units- $\mathrm{k}, \mathrm{m}$, and undivided-contain 


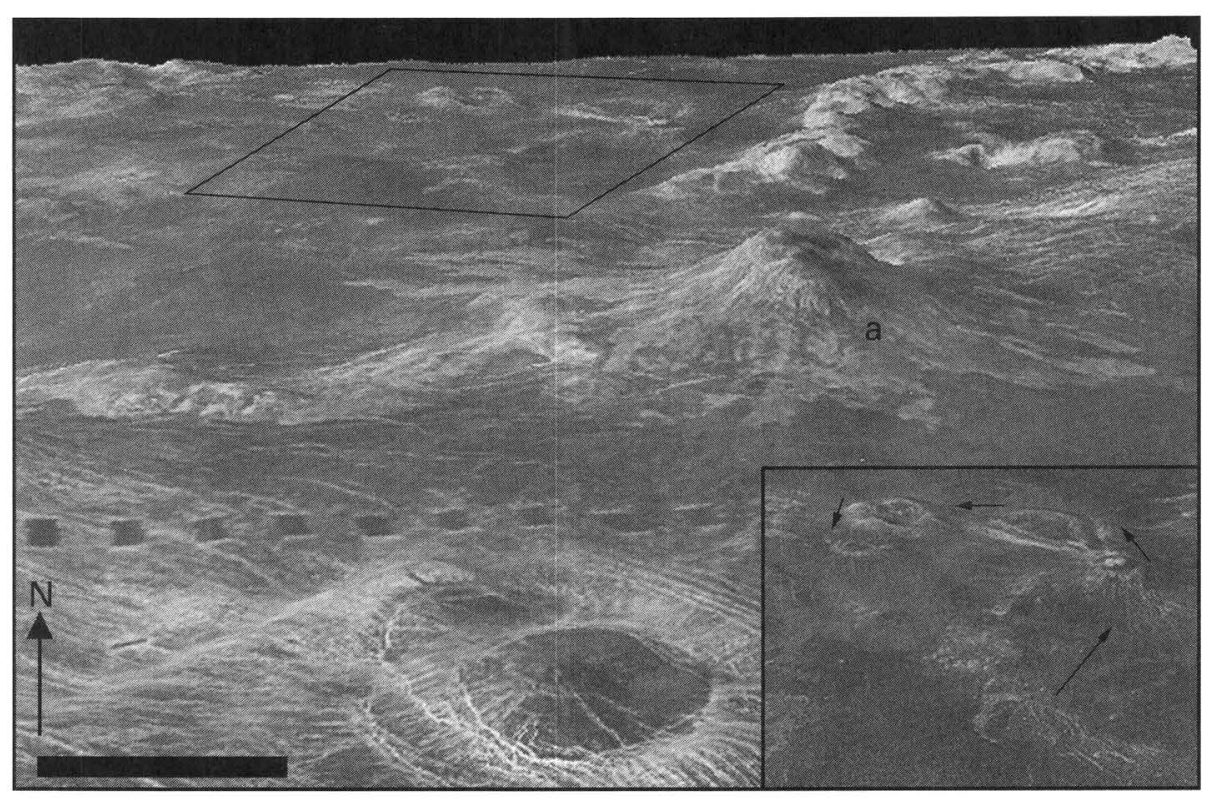

Figure 7. Three-dimensional perspective view of northeast corner of Galindo quadrangle (composed of left-looking synthetic aperature radar images; vertical exaggeration 10x; Kirk and others, 1992); 100-km scale bar accurate for front of view; 2-km-high volcano, Uretsete Mons, marked "a" and shown in figure 6; Nagavonyi Corona in foreground. Outlined arachnoid chain shown in rectangular view in lower right corner. Arrows in rectangular view show migration of arachnoid centers with time and may represent direction of possible movement of small migratory plume (that formed arachnoids) relative to stable surface.

embayed local areas of older ridged plains (unit tpr?) within their upraised constructs. This older material may occur in other coronae, but the bright nature of dense corona lineations on the SAR images may be obscuring it from view. Finally, Stofan and others (1992) list a multiple corona at lat $2^{\circ} \mathrm{S}$., long $243^{\circ}$; however, the radar images, altimetry, and three-dimensional perspective views show one small corona (without much associated material) surrounded by rolling hill topography.

The typical relatively symmetric pattern of concentric and radial structures of coronae is deformed or absent around those coronae associated with extension zones. Instead, these structures have been bent around and deflected about the fractures, grabens, and depressions of the extension zones; the depressions of the zones even form sections of the outer moats of some of the coronae. No coronae along the depression zones can be equivocally shown to postdate the extension. These facts and the interlayered stratigraphy of coronal flows adjacent to extension zones indicate that the coronae are interrelated to growth of their adjacent extension zones. In other words, coronae found along Parga and the northeast rift are likely coeval to the development of the triple junction. Most of the coronae in the map area are related to growth of the triple junction and, although these coronae show systematic variations in age, they do not show a clear evolutionary morphology. However, an arachnoid chain not associated with the triple junction does show a clear age progression of arachnoids along the chain (fig. 7). The morphologies of the arachnoids range from the oldest being topographically negative, followed by ones of various heights along the chain, to the youngest being very slightly elevated (fig. 8). This evolution of arachnoid morphology generally conforms to the corona sequence topography proposed by Stofan and others (1992), which consists of uplift, annulus and trough formation, and finally topographic depression, with volcanism continuing throughout the process. These small arachnoid features may show the predicted evolutionary trend, because they result from what may be a small volume, but deepseated, migratory mantle plume (Chapman and Kirk, 1996). (A much larger stationary hot-spot plume under the triple junction zone could be responsible for the larger coronae that do not show clear evolutionary trends.) An alternative explanation could be that the age progression of the arachnoids indicates a local surface has moved relative to a smaller stable plume. However, this explanation cannot be correct because the direction of earliest movement was south toward a tessera high, part of the western arm of the Phoebe Regio belt (fig. 7), and although the embaying plains and arachnoid material is elevated against the north side of the regio belt, no deformation of these materials occurs within the highlands. Furthermore, the tessera highlands are older than the arachnoids and therefore predate any surface movement.

Solomon and others (1992) stated that the nova stage of corona growth may correspond to the initial arrival near the base of the lithosphere of the quasi-spherical plume head, and Head and others (1992b) noted that there was 


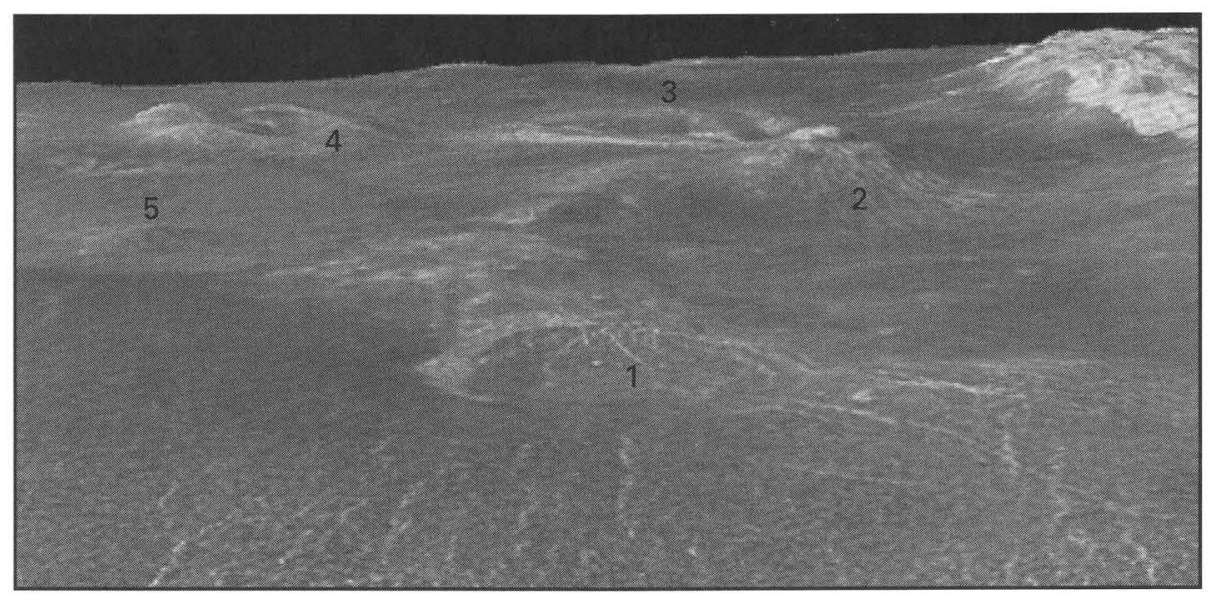

A

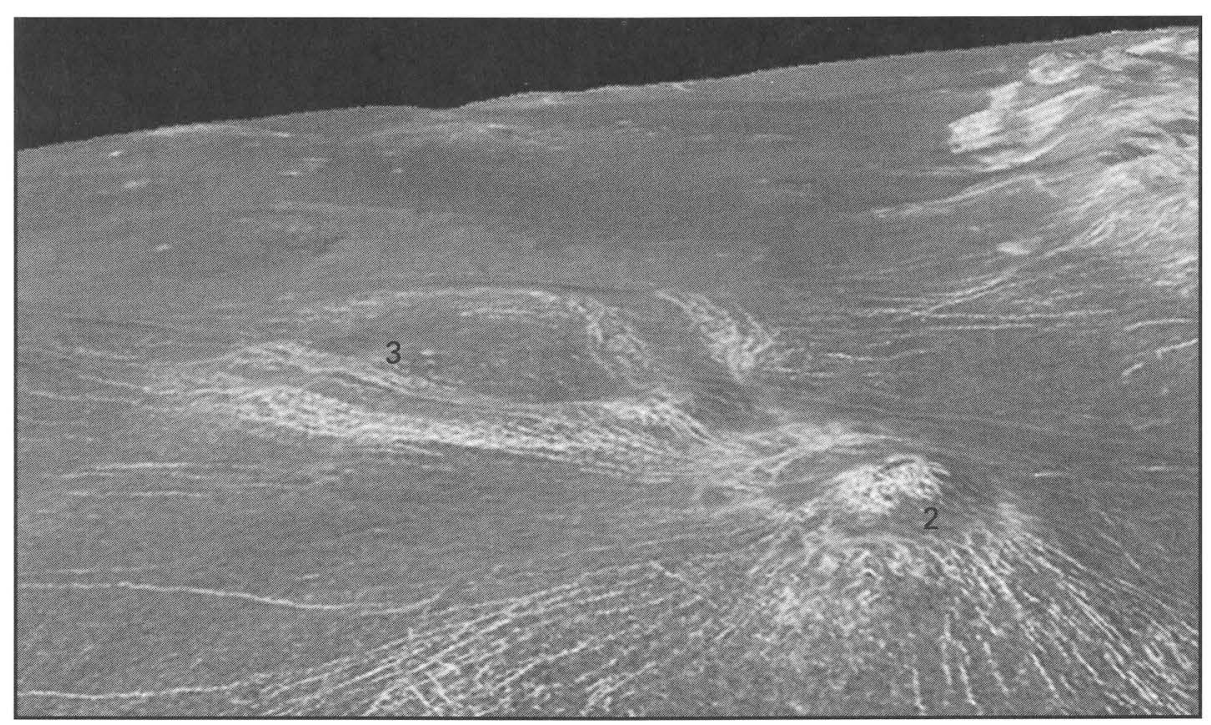

B

Figure 8. Three-dimensional perspective view of arachnoid group (composed of leftlooking synthetic aperature radar images; vertical exaggeration 10x; Kirk and others, 1992) centered at lat $6^{\circ} \mathrm{S}$., long $260^{\circ}$ (shown in fig. 7); arachnoids marked "1-5" are in order of oldest to youngest. Morphologies of arachnoids range from oldest being topographically negative to various heights along the chain to youngest being very slightly elevated (Chapman and Kirk, 1996). A, View toward northeast; 70-km-wide arachnoid 1. B, Close-up of arachnoids 2 and 3 in $A$; view toward northeast. $C$, View toward northwest. $D$, Close-up of arachnoids 4 and 5 in $C$.

some evidence for an evolutionary sequence of features beginning with novae, extending through large volcanoes, and ending in coronae. However, the superposition relation between the two novae in the map area and their underlying corona does not support either of the latter interpretations. There are not enough novae in the map area to further comment on nova origins.

\section{GEOLOGIC SUMMARY}

Phoebe Regio tessera material is the oldest unit in the map area, and most of this material crops out in a belt that trends northeast across the map area. The major structure in the map area is Parga Chasma, which is offset to the south after encountering the Phoebe Regio belt. Parga
Chasma appears to be part of a triple junction rift zone, as grabens are abundant throughout the map area and a less dominant fracture zone trends northeast away from the convex side of the arcuate segment of Parga. Coronae associated with the rift zones seem to be coeval with extension; they and the triple junction may be related to local mantle upwelling of a large quasi-stationary hot-spot plume. An arachnoid chain not associated with the triple junction shows an age progression, possibly indicating that a small plume has migrated relative to the stable surface (Chapman and Kirk, 1996). The youngest events in the map area seem to be the growth of a 2 -km-high shield volcano that embays the Phoebe Regio belt and the formation of an east-west-trending extension zone that fractures the top of the volcano on the east. 

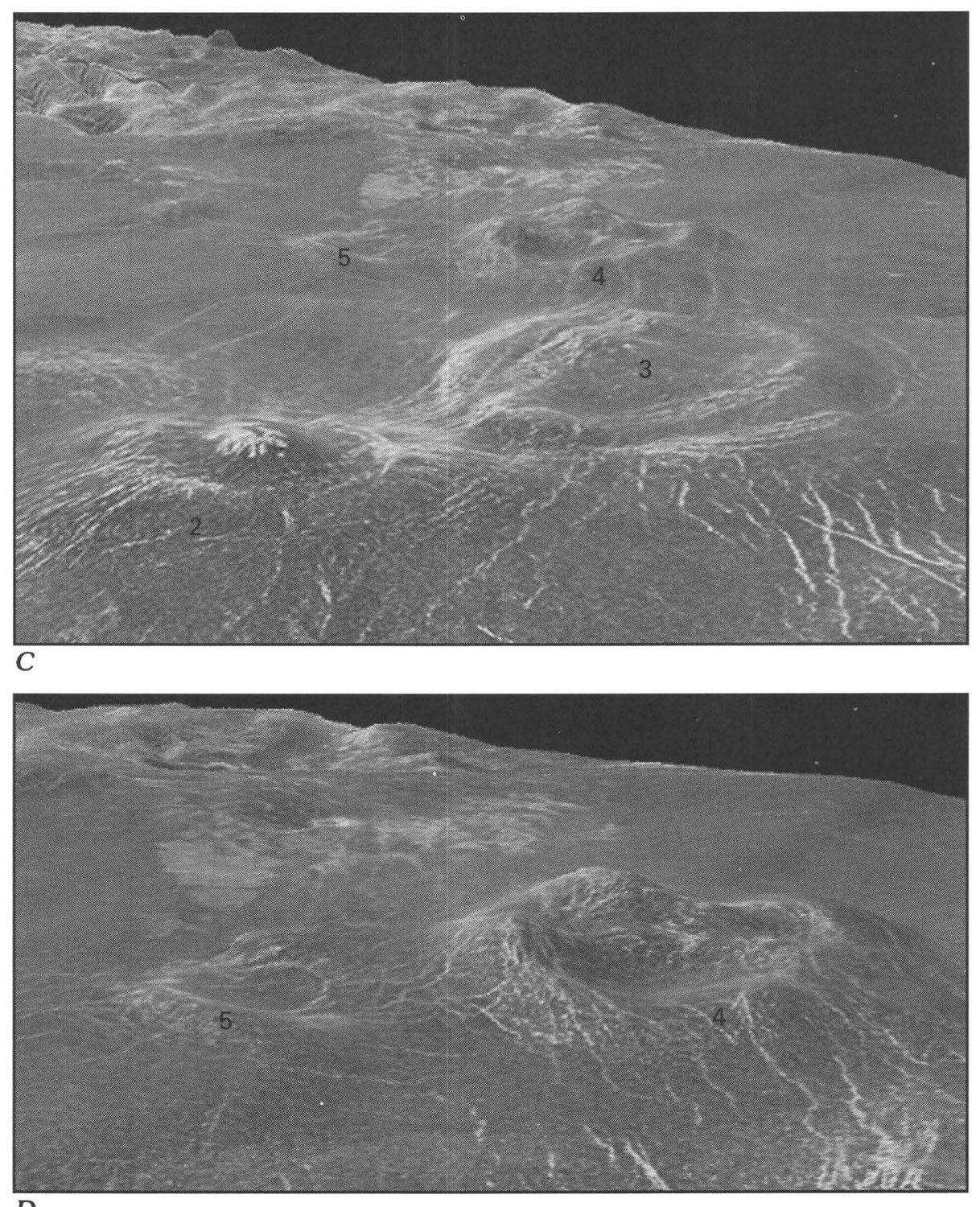

D

Figure 8. Continued.

\section{REFERENCES CITED}

Arkani-Hamed, J. and Toksöz, M.N., 1984, Thermal evolution of Venus: Physics of the Earth and Planetary Interiors, v. 34, p. 232-250.

Baer, Gidon, Schubert, Gerald, Bindschadler, D.L., and Stofan, E.R., 1994, Spatial and temporal relations between coronae and extensional belts, northern Lada Terra, Venus: Journal of Geophysical Research, v. 99, p. 8355-8369.

Barsukov, V.L., Basilevsky, A.T., Kuzmin, R.O., Pronin, A.A., Nikolaeva, O.N., Chernaya, I.M., Burba, G.A., Bobina, N.N., Shahkina, V.P., Markov, M.S., and Sukhanov, A.L., 1984, Geology of Venus from the results of analysis of radar images taken by Venera 15 and Venera 16 probes-Preliminary data: Geochimica et Cosmochimica Acta, v. 12, p. 1811-1820.
Barsukov, V.L., Basilevsky, A.T., Burba, G.A., Bobina, N.N., Kryuchkow, V.P., Kuzmin, R.O., Nikaeva, O.N., Pronin, A.A., Ronca, L.B., Chernaya, I.M., Shashkina, V.P., Garanin, A.V., Kushky, E.R., Markov, M.S., Sukhanov, A.L., Kotelnikov, V.A., Rzhiga, O.N., Petrov, G.M., Alexandrov, Yu.N., Sidorenko, A.I., Bogomolov, A.F., Skrypnik, G.I., Bergman, M.Yu., Kudrin, L.V., Bokshtein, I.M., Knonrod, M.A., Chochia, D.A., Tyuflin, Yu.S., Kadnichansky, S.A., and Akim, E.L., 1986, The geology and geomorphology of the Venus surface as revealed by the radar images obtained by Veneras 15 and 16: Journal of Geophysical Research, v. 91, p. 378-398.

Basilevsky, A.T., Pronin, L.B., Ronca, L.B., Kryuchkov, V.P., and Sukhanov, A.L., 1986, Styles of tectonic deformations on Venus-Analysis of Venera 15 and 16 data, in Proceedings of the 16th Lunar and Planetary 


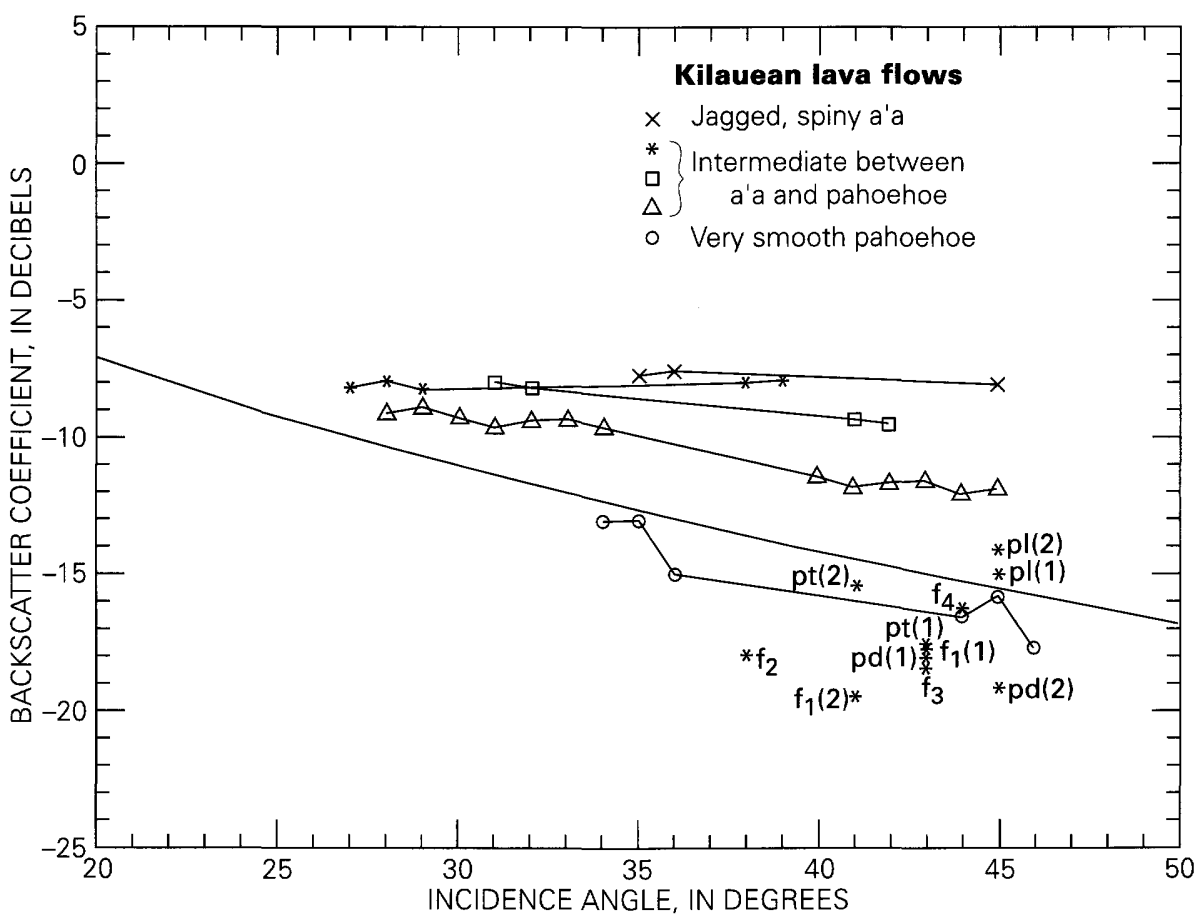

Figure 9. Radar correlation chart; incidence angles of cycle 1 data vary from 35.5 to 44.9 degrees within map area. Points labeled are chosen Venus samples listed in table 1. Compare points with connected plot symbols for five lava flows on Kilauea, whose roughness extends from very smooth pahoehoe (lowest line) to jagged, spiny a'a (upper line; Campbell, 1994). Solid line is average scattering law for Venus defined by Muhleman (1964). Radar-light plains plot above the average scattering value of Venus and have backscatter values higher than other units.

Science Conference, Part 2: Journal of Geophysical Research, v. 91, supplement, p. 399-411.

Batson, R.M., Edwards, K.B., and Eliason, E.M., 1978, Synthetic stereo and LandSat pictures: Photogrammetric Engineering \& Remote Sensing, v. 42. p. 1279-1284.

Bindshadler, D.L., and Head, J.W., 1989, Characterization of Venera 15/16 geologic units from Pioneer Venus reflectivity and roughness data: Icarus, v. 77, p. 3-20.

-1991, Tessera terrain, Venus-Characterization and models for origin and evolution: Journal of Geophysical Research, v. 96, p. 5889-5907.

Campbell, B.A., 1994, Merging Magellan emissivity and SAR data for analysis of Venus surface dielectric properties: Icarus, v. 112, p. 187-203.

Campbell, D.B., and Burns, B.A., 1980, Earth-based radar imagery of Venus: Journal of Geophysical Research, v. 85, p. 8271-8281.

Chapman, M.G., and Kirk, R.L., 1996, A migratory mantle plume on Venus-Implications for the Earth: Journal of Geophysical Research (Solid Earth), v. 101, p. 15953-15967.

Chapman, M.G., Kirk, R.L., and Barrett, J.M., 1994, 3-D perspective imaging-A tool for geologic mapping of Venus, in Abstracts submitted to the 25th Lunar and Planetary Science Conference, March 15-19, 1994:
Houston, Lunar and Planetary Institute, p. 239-240.

Ford, J.P., and Plaut, J.L., 1993, Magellan image data, in Guide to Magellan image interpretation: Jet Propulsion Laboratory Publication 93-24, p. 7-18.

Hansen, V.L., Keep, M., Herrick, R.R., and Phillips, R.J., 1992, Tectonics and volcanism of eastern Aphrodite Terra-No subduction, no spreading, in Papers presented to the International Colloquium on Venus, August 10-12, 1992: Pasadena, California, Lunar and Planetary Institute, p. 40-41.

Head, J.W., Crumpler, Larry, Aubele, Jane, Guest, John, Saunders, R.S., 1992a, Venus volcanism-Classification of volcanic features and structures, associations, and global distribution from Magellan data: Journal of Geophysical Research, v. 97, p.13,153-13,198.

Head, J.W., Crumpler, Larry, Aubele, Jane, and the Magellan Team, 1992b, Venus volcanism-A global overview from Magellan data: Papers presented to the International Colloquium on Venus, August 10-12, 1992: Pasadena, California, Lunar and Planetary Institute, $\mathrm{p}$. 43-45.

Herrick, R.R., 1994, Resurfacing history of Venus: Geology, v. 22, p. 703-706.

Janes, D.M., Squyres, S.W., Bindschadler, D.L., Baer, G., Schubert, G., Sharpton, V.L., and Stofan, E.R., 1992, Geophysical models for the formation and evolution of 
coronae on Venus: Journal of Geophysical Research, v. 97, p. $16,055-16,067$.

Kirk, R.L., Soderblom, L.A., and Lee, E.M., 1992, Enhanced visualization for interpretation of Magellan radar data: Supplement to the Magellan special issue: Journal of Geophysical Research, v. 97, p. $16,371-16,380$.

Luongo, G., Cubellis, E., Obrizzo, F., and Petrazzuoli, S.M., 1991, A physical model for the origin of volcanism of the Tyrrhenian margin-The case of the Neapolitan area: Journal of Volcanology and Geothermal Research, v. 48 , p. $173-185$.

Muhleman, D.O., 1964, Radar scattering from Venus and the Moon: Astronomical Journal, v. 69, p. 34-41.

Parmentier, E.M., and Hess, P.C., 1992, Chemical differentiation of a convecting planetary interior-Consequences for a one-plate planet such as Venus: Geophysical Research Letters, v. 19, p. 2015-2018.

Pettengill, G.H., Ford, P.G., Johnson, W.T.K., Raney, R.K., Soderblom, L.A., 1991, Magellan radar performance and data products, Science, v. 252, p. 260-265.

Phillips, R.J., Raubertas, R.F., Arvidson, R.E., Sarkar, I.C., Herrick, R.R., Izenberg, N., and Grimm, R.E., 1992, Impact crater distribution and the resurfacing history of Venus: Journal of Geophysical Research, v. 97, p. $15,923-15,948$.

Plaut, J.L., 1993, Stereo imaging, in Guide to Magellan image interpretation: Jet Propulsion Laboratory Publication 93-24, p. 33-44.

Pronin, A.A., and Stofan, E.R., 1990, Coronae on VenusMorphology, classification, and distribution: Icarus, v. 87 , p. $452-474$.

Sandwell, D.T., and Schubert, Gerald, 1992, Flexural ridges, trenches, and outer rises around coronae on Venus: Journal of Geophysical Research, v. 97, p. $16,069-16,083$.

Schaber, G.G., and Boyce, Joseph, 1977, Probable distribution of large impact basins on Venus-Comparisons with Mercury and the Moon, in Impact and explosion cratering: Elmsford, NY, Pergamon Press, $p$. 603-612.

Schaber, G.G., Moore, H.J., Strom, R.G., and Boyce, J.M., 1992, The uniform distribution but nonuniform modification of impact craters on Venus, in Abstracts submitted to the 23d Lunar and Planetary Science Conference, March 15-19, 1992: Houston, Lunar and Planetary Institute, p. 1213-1214.

Schubert, Gerald, Bercovici, D., and Glatzmaier, G.A., 1990, Mantle dynamics in Mars and Venus-Influence of an immobile lithosphere on three-dimensional mantle convection: Journal of Geophysical Research, v. 95, p. 14105-14129.

Schubert, Gerald, Bercovici, D., Thomas, P.J., and Campbell, D.B., 1989, Venus coronae-Formation by mantle plumes, in Abstracts submitted to the 20th Lunar and Planetary Science Conference, March 16-20, 1989: Houston, Lunar and Planetary Institute, p. 968-969.

Schubert, Gerald, Moore, W.B., and Sandwell, D.T., 1994, Gravity over coronae and chasmata on Venus: Icarus, v. 112, p. 130-146.

Soderblom, L.A., Kirk, R.L., Chapman, M.G., and Barrett, J.M., 1993, Poor man's visualization of Venus or terrain animation for the economically challenged [abs.]: National Aeronautics and Space Administration Planetary Data Visualization Conference, Nov. 15-17, San Juan Capistrano, CA, p. 38-39.

Solomon, S.C., Smrekar, S.E., Bindschadler, D.L., Grimm, R.E., Kaula, W.M., McGill, G.E., Phillips, R.J., Saunders, R.S., Schubert, G., Squyres, S.W., Stofan, E.R., 1992, Venus tectonics-An overview of Magellan observations: Journal of Geophysical Research, v. 97, p. 13,199-13,256.

Squyres, S.W., Janes, D.M., Baer, G., Bindschadler, D.L., Schubert, G., Scharpton, V.L., and Stofan, E.R., 1992, The morphology and evolution of coronae and novae on Venus: Journal of Geophysical Research, v. 97, p. $13,611-13,634$.

Stofan, E.R., and Head, J.W., 1990, Coronae of Mnemosyne Regio-Morphology and origin: Icarus, v. 83, p. 216-243.

Stofan, E.R., Sharpton, V.L., Schubert, G., Baer, G., Bindschadler, D.L., Janes, D.M., Squyres, S.W., 1992, Global distribution and characteristics of coronae and related features on Venus-Implications for origin and relation to mantle processes: Journal of Geophysical Research, v. 97, p. 13,347-13,378.

Strom, R.G., Schaber, G.G., Arkani-Hamed, J., and Toksöz, M.N., 1992, Global resurfacing of Venus, in Abstracts submitted to the 23d Lunar and Planetary Science Conference, March 15-19, 1992: Houston, Lunar and Planetary Institute, p. 1379-1380.

Turcotte, D.L., 1993, An episodic hypothesis for venusian tectonics: Journal of Geophysical Research, v. 98, p. 17,061-17,068.

White, Robert, and McKenzie, Dan, 1989, Magmatism at rift zones: The generation of volcanic continental margins and flood basalts: Journal of Geophysical Research, v. 94 , p. $7685-7729$. 


